\title{
Presence of Palaeoproterozoic and Archean components in the granulite-facies rocks of central Iberia: The Hf isotopic evidence
}

\author{
C. Villaseca ${ }^{\mathrm{a}, *}$, E. Belousova $^{\mathrm{b}}$, D. Orejana ${ }^{\mathrm{a}}$, P. Castiñeiras ${ }^{\mathrm{a}}$, C. Pérez-Soba ${ }^{\mathrm{a}}$

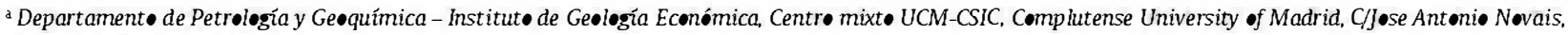 \\ 2, 28040 Madrid, Spain \\ - GEMOC, ARC National Key Centre, Department of Earth and Planetary Sciences, Macquarie University, Sydney NSW 2109, Australia
}

Keywords:

Migmatite

Granulite

$\mathrm{U}-\mathrm{Pb}$ age

Zircon Hf isotope

Central Iberian Zone

Crustal recycling

\begin{abstract}
A B S T R A C T

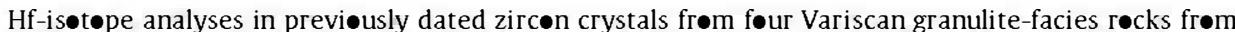

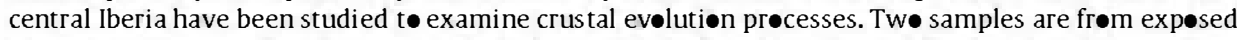

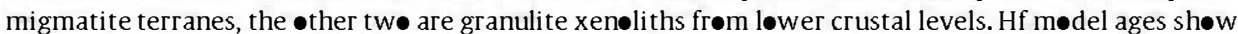

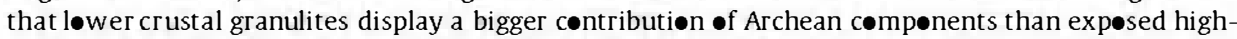

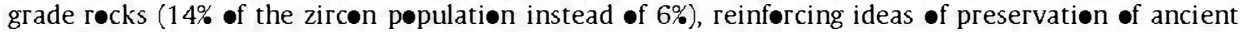

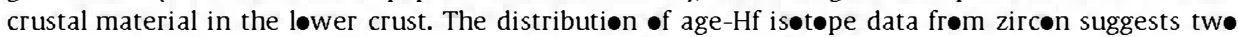

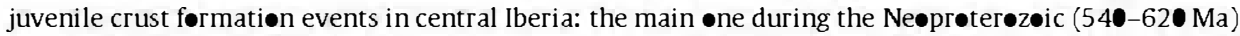

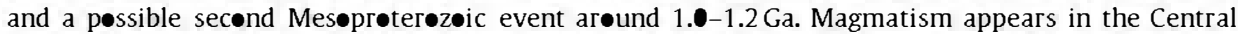

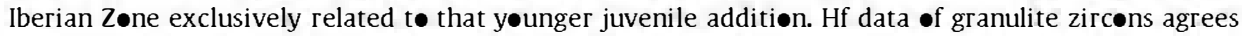
with recent palae@ge graphical reconstruction mødels which present central Iberia as a peri-Gøndwanan terrane located between the West African craton and the Arabian shield, far from the Amazonia microplate.
\end{abstract}

\section{Introduction}

Partial melting is a common geological process in high-grade metamorphic terranes (e.g., Clemens, 1990; Brown, 2001; Liu et al., 2010). Establishing the age of partial melting events in an orogen is crucial for understanding the relationships among partial melting, metamorphic evolution and orogenic processes. Zircon is a hard refractory mineral which incorporates modest amounts of $\mathrm{U}$ and $\mathrm{Th}$, and has very low rates of $\mathrm{Pb}$ diffusion (Cherniak and Watson, 2003), leading to precise U-Pb dating of partial melting events. The extremely stable nature of zircon and its high closure temperature for $\mathrm{U}-\mathrm{Pb}$ diffusion means that its isotopic system is little disturbed by metamorphism and migmatization. Lu-Hf zircon data is a formidable tracer of the processes involved in melting scenarios: melt and residuum segregation, restite entrainment, zircon dissolution or precipitation, zircon inheritance, etc. Thus, U-Pb geochronological data combined with spot analyses of Hf isotopic composition of zircon can be used not only to trace source characteristics, but also to reveal processes involved in the generation of crustal melts and residual granulitic rocks (e.g., Flowerdew et al., 2006; Wu et al., 2007; Orejana et al., 2011).

\footnotetext{
* Correspond ing author. Tel.: +34913944910; fax: +34915442535.

E-mail address: granito@geo.ucm.es (C. Villaseca).
}

Evidence of partial melting in central Spain appears in two distinct high grade metamorphic environments. The first group is represented by outcropping migmatite terranes of granulite-facies conditions, whereas the second lithological assemblage corresponds to granulite xenoliths sampled from deep-seated lower crustal levels by Upper Permian alkaline lamprophyres (Villaseca et al., 2001). In migmatite terranes a complex association of leucosomes, residual migmatites, restite-rich granites and anatectic leucogranites appear. We have sampled two anatectic complexes: Sotosalbos and Toledo (Fig. 1). The Sotosalbos area is located in the northeast portion of the Spanish Central System (SCS) and is a high-grade area with local migmatization giving rise to some banded migmatites and a diatexitic or restite-rich granite (Sotosalbos granite, Martín Romera et al., 1999). The dominant country rock in this region (the likely protolith of the restite-rich granite) is metagranitic augen gneiss, which yielded a mean age of $464 \mathrm{Ma}$ (Castiñeiras et al., 2008a). Partial melting conditions were $725^{\circ} \mathrm{C}$ and $4-5 \mathrm{~kb}$ (Martín Romera et al., 1999), attained during the Variscan exhumation which occurred in the age range of 337-330 Ma (Escuder Viruete et al., 1998; Castiñeiras et al., 2008a). The Anatectic Complex of Toledo (ACT) is mainly constituted by metasediment-derived migmatites. Averaged ACT metamorphic peak conditions are $800^{\circ} \mathrm{C}$ and $4-6 \mathrm{~kb}$, with a poorly constrained age ranging from 301 to $317 \mathrm{Ma}$ (Barbero and Rogers, 1999; Bea et al., 2006; Castiñeiras et al., 2008a). 


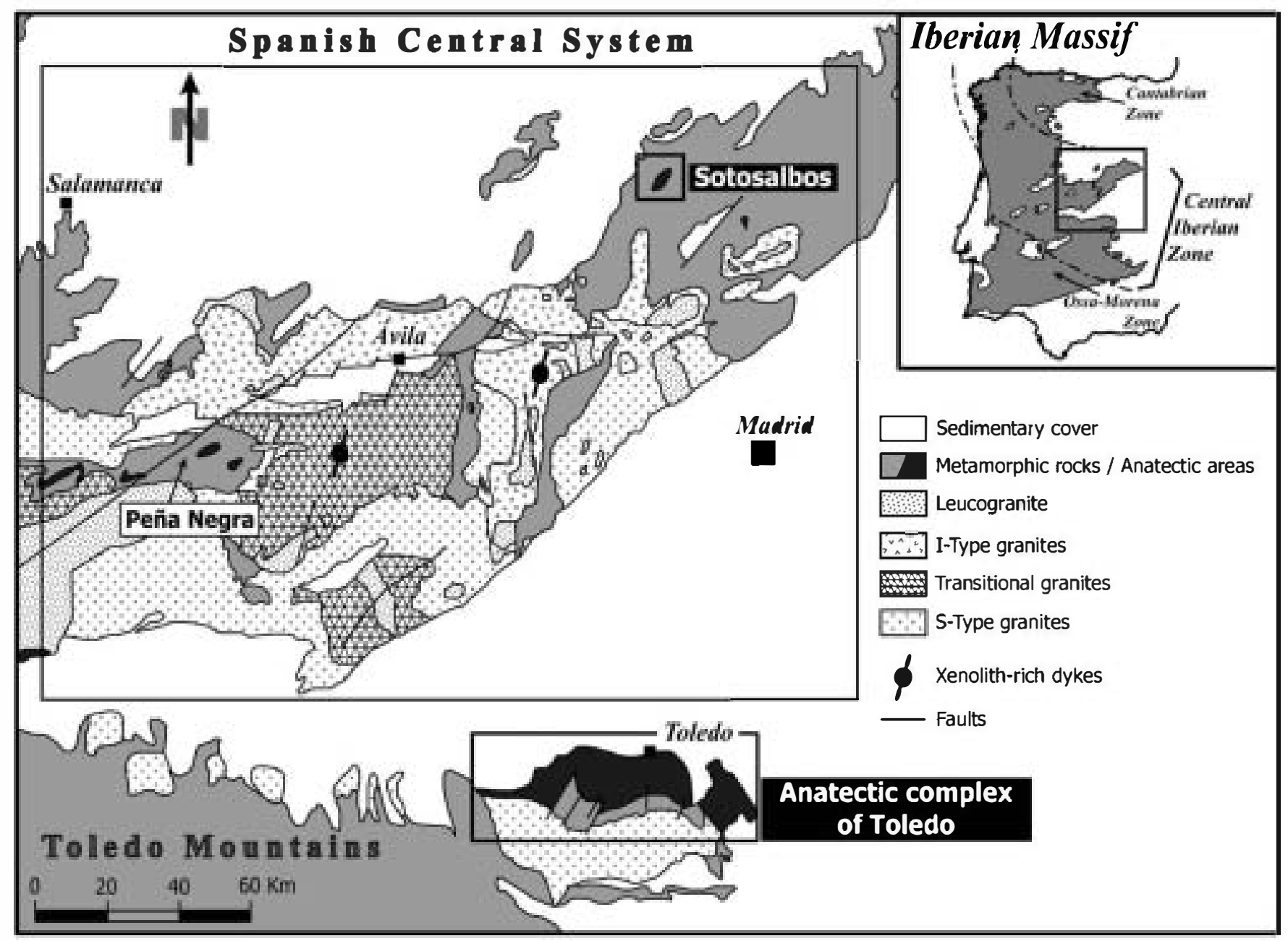

Fig. 1. Geological map of central Spain showing the location of the stud ied Variscan high-grade terranes and the granulite xenolith-rich outcrops. The zones of the Iberian Massif are after Julivert et al. (1972) (inset).

A granulitic xenolith suite from lower crustal depths appears as enclaves in Upper Permian alkaline lamprophyres. It has been interpreted as the residual keel of the outcropping peraluminous SCS granitic batholith (Villaseca et al., 1999). P-T estimates give granulite-facies conditions around $900-1000^{\circ} \mathrm{C}$ and $8-11 \mathrm{~kb}$ (Villaseca et al., 1999; Villaseca and Orejana, 2008; Orejana et al., 2011). Whole-rock geochemistry (including $\mathrm{Sr}-\mathrm{Nd}-0-\mathrm{Pb}$ isotope data) is consistent with the late-Variscan granites as melts in equilibrium with these residual lower-crustal granulite xenoliths (Villaseca et al., 1999, 2009). Moreover, U-Pb zircon dating in these granulites yields a group of Variscan ages (320-283 Ma) which match the SCS granite intrusion ages and reinforces the hypothesis of generation of these felsic magmas in the lower crust (FernándezSuárez et al., 2006; Orejana et al., 2011).

Thus, samples used for this work represent material coming from different crustal levels (middle to lower crust, Villaseca et al., 2001) and they contain different proportions of melt and residual components after the partial melting process. The two samples from migmatite terranes are an anatectic leucogranite (melt-rich migmatite: Cervatos granite from the ACT) and a restite-rich granite (Sotosalbos diatexite). Two felsic granulite xenoliths represent extreme residual granulite assemblages, scavenged from lower crustal levels, close to the Moho (Villaseca et al., 1999). In this paper we present Lu-Hf analysis by laser ablation-inductivelycoupled plasma-mass spectrometry ( LA-ICPMS) performed on zircons previously dated using sensitive high-resolution ion-microprobe (SHRIMP). Our new results not only provide information on the nature of the granulite protolith source but also have implications on the complex geodynamic evolution of the orogenic Iberian Variscan Belt.

\section{Geological setting}

The Sotosalbos and ACT complexes crop out in central Spain, within the Central Iberian Zone ( $\mathrm{CIZ}$ ), the innermost part of the Iberian Massif (Fig. 1). This orogenic sector is mainly composed of plutonic and variably metamorphosed rocks, including several migmatite complexes. Available petrological data indicate that high-grade areas of central Spain could have evolved following a clockwise $P-T-t$ path, from peak pressure of $\sim 14 \mathrm{~kb}$ (eclogite to high-P granulite conditions) towards pressures of 4-5 kb (Barbero and Villaseca, 2000). Migmatization is related to the low-P loop, when temperature was decreasing (Villaseca and Ubanell, 2005; Castiñeiras et al., 2008a).

The Sotosalbos complex is mainly composed of augen orthogneisses showing low degree of migmatization, excepting the mobilised restite-rich granite which crops out in a $1 \mathrm{~km} \times 0.3 \mathrm{~km}$ massif (Martín Romera et al., 1999). This granite (sample 100560) is a highly peraluminous monzogranite with cordierite and biotite as mafic minerals, which are also common in other anatectic areas of the SCS (e.g., Peña Negra complex, Bea et al., 1994; Pereira and Rodríguez Alonso, 2000). Its mineral paragenesis indicates not only low $P_{-} T$ granulite-facies conditions $\left(4 \pm 1 \mathrm{~kb}\right.$ and $\left.725 \pm 50^{\circ} \mathrm{C}\right)$ but 
also low melting fractions in a water available melting process (biotite-rich selvedges and melanosomes are common, Villaseca et al., 2001). Even though the Sotosalbos diatexitic granite is a segregated melt-poor migmatite, high-grade metamorphic rocks with at least $8 \%$ melt fraction can flow and mechanically behave as an ensemble with higher melt fractions (Rosenberg and Handy, 2005). The conspicuous presence in this granite of orthogneissic xenoliths, and dispersed and variably corroded augen K-feldspars, together with the predominance of meta-igneous inherited zircons (>90\% zircon population; Castiñeiras et al., 2008a) corroborates the high amount of residual components within it. A petrographic description of this restite-rich granite has been detailed in previous papers (Villaseca et al., 2001; Castiñeiras et al., 2008a).

Migmatites from the ACT are mostly metasedimentary-derived. High temperature granulite-facies conditions and the predominance of pelite layers give rise to a greater variety of migmatite types. The biotite scarcity in all ACT migmatites is indicative of the surpassing of the biotite dehydration melting reaction and the more extreme conditions attained during partial melting in this area $\left(800 \pm 25^{\circ} \mathrm{C}\right.$ and $5 \pm 1 \mathrm{~kb}$, after Barbero, 1995). Melt-rich migmatites (leucogranites) appear either as meter-thick dykes or as km-size massifs. Less segregated melt-residuum migmatites also appear (e.g., banded leucosome-mesosome migmatites, restiterich granites, Barbero et al., 1995; Villaseca et al., 2001). The sampled Cervatos leucogranite (sample CV1) is a peraluminous eutectic-like granite showing mostly mafic anhydrous minerals (garnet or cordierite), with late accessory biotite (Barbero et al., 1995; Villaseca et al., 2001; Castiñeiras et al., 2008a).

The two studied felsic granulite xenoliths (U145 and U152) are representative of the most abundant lower crustal granulitetype included in ultrabasic-basic alkaline lamprophyres (Villaseca et al., 1999). They are mainly composed by K-feldspar, quartz and garnet, with minor amounts of plagioclase, sillimanite, rutile and Al-phlogopite. The main accessory minerals are apatite, zircon and monazite. The zircon trace element composition indicates that inherited cores have typical igneous features such as oscillatory zoning, high Th/U ratios and positive Ce anomalies (-rejana et al., 2011). An abundant peraluminous magmatic activity was developed within the eastern Spanish Central System approximately from 468 to $500 \mathrm{Ma}$ (e.g., Bea et al., 2007; Castiñeiras et al., 2008a). The predominance of zircon inheritances with ages in the range of 460-535 Ma (Fernández-Suárez et al., 2006; Orejana et al., 2011) suggests that Cambro-Ordovician orthogneisses could be an appropriate igneous protolith for these granulites. This is reinforced by geochemical mass balance calculations of partial melting using the orthogneisses as protoliths and the granulite xenoliths as residua, and also by the similitude in their initial $\mathrm{Nd}$ isotopic composition (Villaseca et al., 1999). Nevertheless, granulite U152 contains Archean zircon age inheritances, which are common in CIZ metasediments (Gutiérrez-Alonso et al., 2003; Castiñeiras et al., 2008a). Thus, the nature of lower crustal granulite protoliths is still a matter of debate.

\section{Analytical methods}

Zircons were separated from whole rock using standard crushing and mineral separation techniques, and hand picked before mounting on double-sided tape on glass slides in $1 \mathrm{~mm} \times 6 \mathrm{~mm}$ parallel rows together with some chips of zircon standard. After setting in epoxy resin, zircons were ground down to expose their central portions and imaged with transmitted and reflected light on a petrographic microscope, and with cathodoluminescence to identify internal structures, inclusions, fractures and other crystal defects. Zircon U-Pb analyses were previously performed using SHRIMPRG either at the Research School of Earth Sciences, of the Australian
National University (felsic granulite xenoliths U145-U152, Orejana et al., 2011), or at the USGS-Standford University (Sotosalbos and ACT samples, Castiñeiras et al., 2008a). Uncertainties and U-Pb data were published and thoroughly discussed in those works. Because inaccurate $\mathrm{U}-\mathrm{Pb}$ ages would result in artificial trends of the $\mathrm{Hf}$ isotopic compositions, we have not used the data obtained with $>27 \%$ discordance for the following discussions, in a similar way to recent studies (e.g., lizuka et al., 2010).

Lu-Hf isotopes were analyzed on the same SHRIMP spots. Hf isotope analyses were performed using a New Wave Research LUV213 laser-ablation microprobe, attached to a Nu Plasma multicollector ICPMS at the GEMOC Key Centre, Macquarie University, Sydney. The laser system delivers a beam of $213 \mathrm{~nm}$ UV light from a frequency-quintupled Nd:YAG laser. Analyses were carried out witha beam diameter of $40-55 \mu \mathrm{m}$, a $5 \mathrm{~Hz}$ repetition rate, and energies of $5-7 \mathrm{~mJ} / \mathrm{cm}^{2}$. This results in total Hf signals of $1-6 \times 10^{-11} \mathrm{~A}$, depending on conditions and Hf contents. Typical ablation times are $100-120$ s, resulting in pits 30-40 $\mu \mathrm{m}$ deep. Ar carrier gas transports the ablated sample from the laser-ablation cell via a mixing chamber to the ICPMS torch. The Nu Plasma MC-ICPMS features and other analytical procedures are those described by Griffin et al. (2002, 2004).

To evaluate the accuracy and precision of the laser-ablation results, and to test the reliability of the correction protocols, we have repeatedly analysed two zircon standards: 91,500 and Mud Tank (MT). These reference zircons gave ${ }^{176} \mathrm{Hf} /{ }^{177} \mathrm{Hf}=0.282310 \pm 0.000049(2 \sigma)$ and $0.282502 \pm 0.000044$ $(2 \sigma)$, respectively, which are identical to average published values on solutions of $0.282306 \pm 0.000008$ for 91,500 and $0.282507 \pm 0.000006$ for MT (Woodhead and Hergt, 2005). The $2 \sigma$ uncertainty on a single analysis of ${ }^{176} \mathrm{Lu} /{ }^{177} \mathrm{Hf}$ is $\pm 0.001-0.002 \%$ (about 1 epsilon unit), reflecting both analytical uncertainties and the spatial variation of Lu/Hf across many zircons. The ${ }^{176} \mathrm{Lu}$ decay constant value of $1.865 \times 10^{-11} \mathrm{a}^{-1}$ was used in all calculations (Scherer et al., 2001). Chondritic ${ }^{176} \mathrm{Hf} /{ }^{177} \mathrm{Hf}=0.282772$ and ${ }^{176} \mathrm{Lu} /{ }^{177} \mathrm{Hf}=0.0332$ (Bouvier et al., 2008) and the depleted mantle ${ }^{176} \mathrm{Hf} /{ }^{177} \mathrm{Hf}=0.28325(\varepsilon \mathrm{Hf}=+16.4)$ and ${ }^{176} \mathrm{Lu} /{ }^{177} \mathrm{Hf}=0.0384$ were applied to calculate $\varepsilon \mathrm{Hf}$ values and model ages used in this work.

\section{Zircon petrography and geochronology}

Although $\mathrm{U}-\mathrm{Pb}$ geochronology and zircon petrography have been previously described by Castiñeiras et al. (2008a) and -rejana et al. (2011), a brief summary of the most remarkable features is given here.

\subsection{Sotosalbos restite-rich granite, 100560}

Three different zircon populations can be distinguished in this cordierite-bearing granitoid. The first group, Variscan narrow dark rims in some grains, represents a very low amount of zircon age population $(<5 \%)$, and yields an age range of $390-335 \mathrm{Ma}$ (Castiñeiras et al., 2008a). The second group comprises the more abundant Cambro-Ordovician magmatic elongated zircons, showing oscillatory zoning (Fig. 2A, \#1, 3, 9). They represent the $\sim 20 \%$ of the zircon population, yielding a predominant mean age of $464 \pm 2.6 \mathrm{Ma}$ (Castiñeiras et al., 2008a), the best estimate to this lower Palaezoic felsic magmatism. The third zircon group comprises the inherited grains, the most abundant zircon type ( $>75 \%$ zircon population), as was also stated by Bea et al. (2007) in a summarial work on this Cambro-Ordovician magmatic event. This zircon group varies from small almost rounded grains (Fig. 2A,\#13) to big elongated crystals, showing lower aspect ratios than the Ordovician magmatic types (Fig. 2A, \#6, 7, 10, 17). We have not found inherited zircon grains without overgrowths, as previously 
(A) 100560

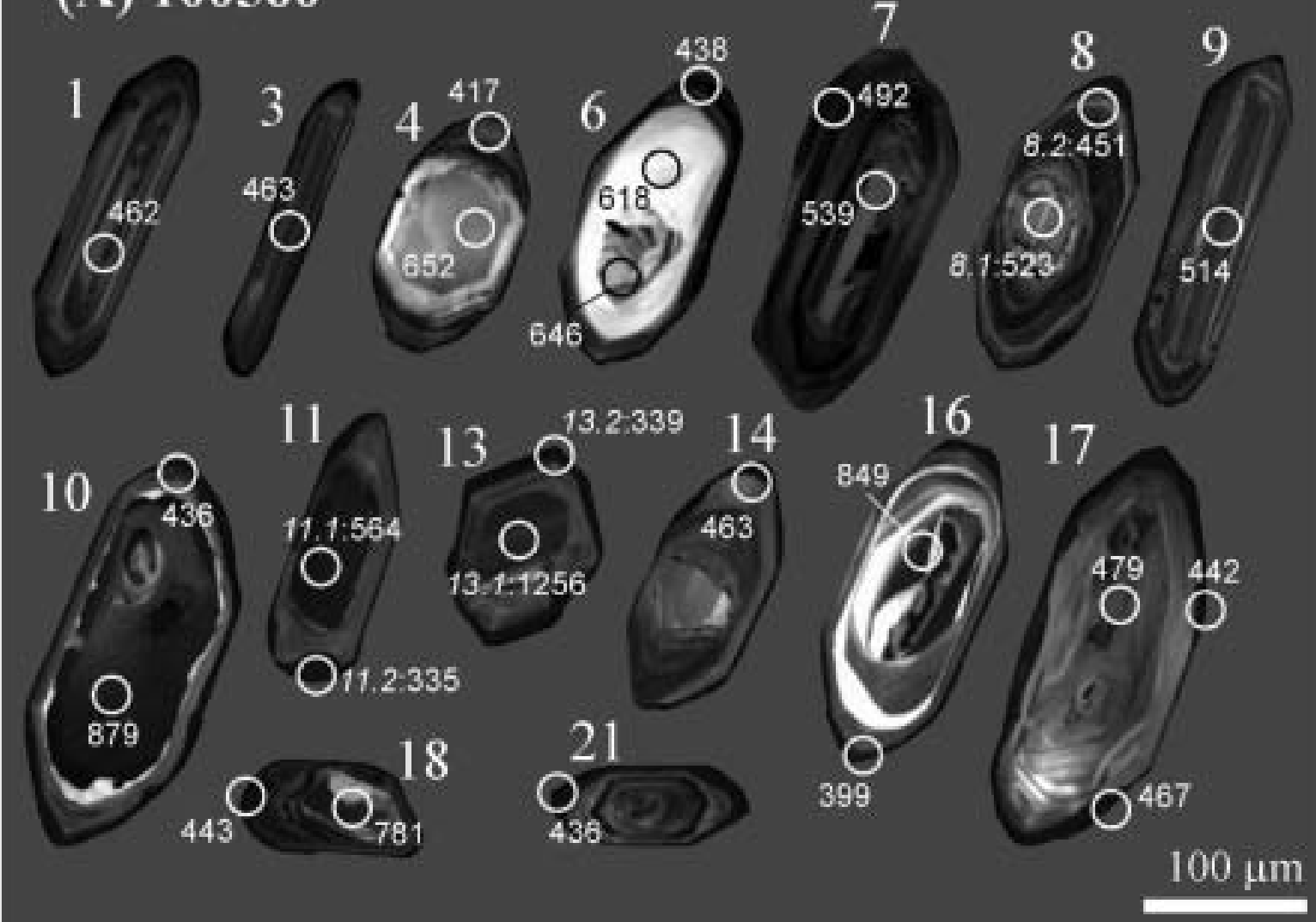

(B) $\mathrm{CV}$-1
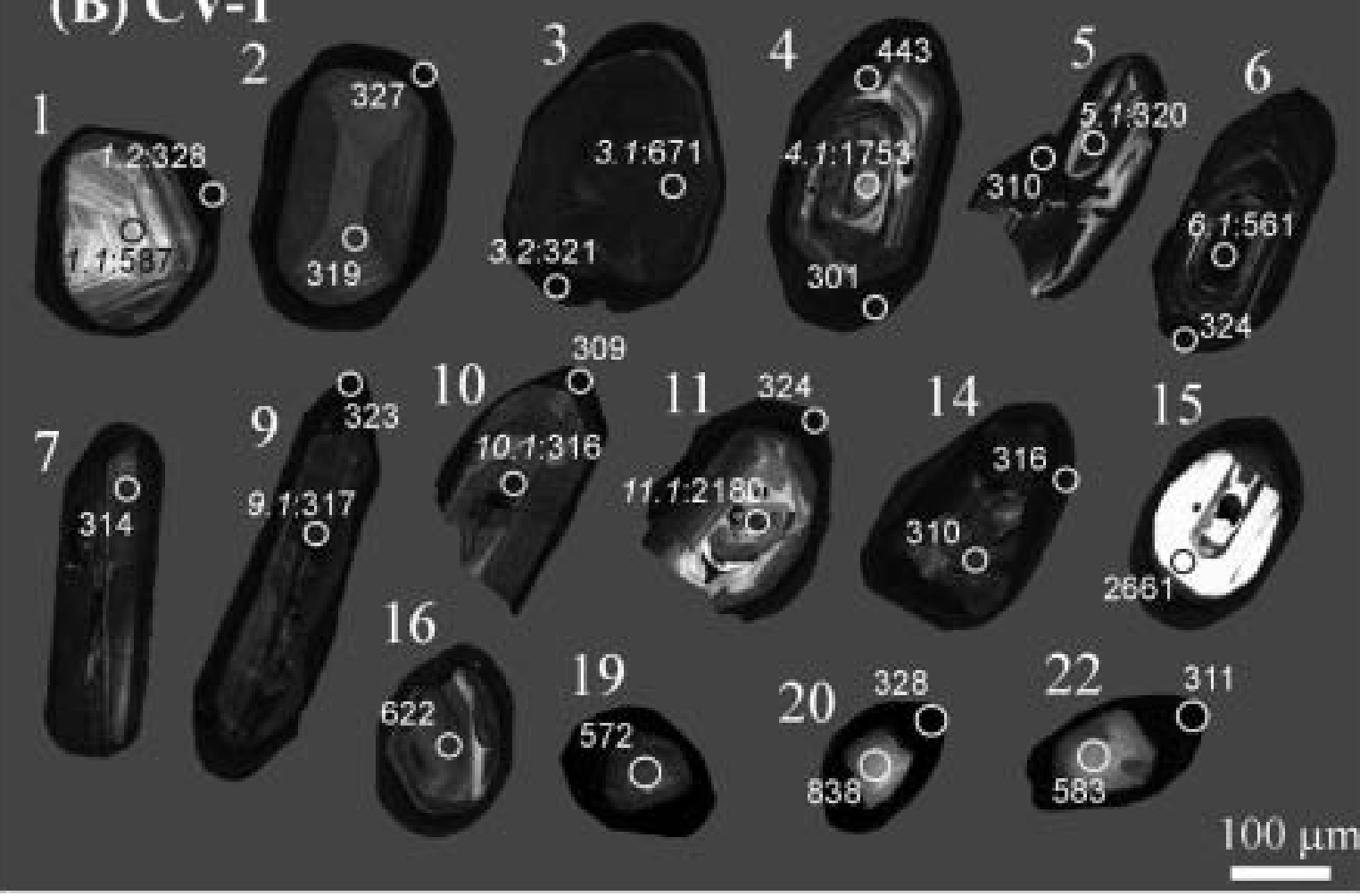

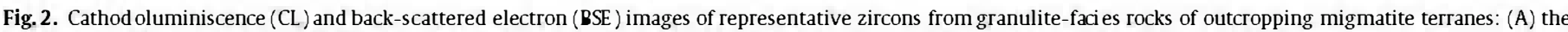
Sotosalbos restite-rich granite (100560), and (B) the Cervatos anatectic leucogranite (CV1). Spot numbers and ages are those listed in Table 1. 
described by Bea et al. (2007). They always present an irregular dark rim of variable thickness, usually representing less than $10 \%$ of the zircon grain, and show ages ranging from those of the Ordovician magmatic event to the extremely limited Variscan recrystallization (Fig. 2A, \#4, 6, 7, 8, 10, 14, 17, 18, 21). Although $\mathrm{U}-\mathrm{Pb}$ dating is limited to 35 spots, inherited data gave age clusters mainly at the early Palaeozoic and Neoproterozoic (514-585 Ma, 620-650 Ma and 780-880Ma), and a single near-concordant (3\% of discordance, Castiñeiras et al., 2008a) analysis yielded $1256 \mathrm{Ma}$ (Fig. 2A, \#13). Inherited zircon cores of early Palaeozoic age show clear oscillatory zoning indicating a probable magmatic origin (Fig. 2A, $\# 7,9$ ), but this feature is poorly defined in other inherited cores (e.g., Fig. 2A, \#4).

\subsection{Cervatos leucogranite, CV1}

Zircons from this anatectic leucogranite are highly variable but can be grouped in at least three main types ( Fig. 2B). An important group is defined by the Variscan magmatic zircon cores, representing the dominant population ( $70 \%)$, and giving an averaged mean age of $317 \pm 3.6 \mathrm{Ma}$ (Castiñeiras et al., 2008a). These magmatic crystals usually display oscillatory or sector zoning (Fig. 2B, $\# 7,9$ ). A second group is represented by narrow dark rims of similar age (Fig. 2B, \#2, 5, 9, 10, 14), although with more than 50\% of cases yielding incongruent older $\mathrm{U}-\mathrm{Pb}$ rim ages than Variscan cores (Fig. 2B, \#2, 9, 14), which suggests secondary modifications occurring during the relatively slow cooling of the anatectic complex (Pidgeon et al., 1998). The third group comprises inherited zircons that appear exclusively as cores in subeuhedral to anhedral crystals (Fig. 2B, \#1, 3, 4, 6, 11, 15, 16, 19, 20, 22), of lower aspect ratios than elongated magmatic zircons. Inherited ages range from the supposedly depositional age of the metasedimentary protolith ( $\sim 560 \mathrm{Ma})$, to scattered ages of 570-670,840,1750, 2180 and $2660 \mathrm{Ma}$ (Castiñeiras et al., 2008a), all of them with discordance lower than $25 \%$. The 560-580 aged cores preserve truncated oscillatory zoning of magmatic aspect (Fig. 2B, \#1, 6).

\subsection{Granulitexenolith, $U 145$}

Zircons in this sample vary from common rounded ( 70\%) to slightly elongated grains ( 30\%) (Orejana et al., 2011). They are more anhedral and equant in average than zircons in samples from migmatite terranes. Around 50\% of crystals show inherited cores with variable degree of resorption (Fig. 3A). Variscan granulitic zircons, in the broad age range of 274-320 Ma, display poorly defined sector zoning (Fig. 3A, \#5, 6, 11, 13, 19). Nevertheless, some Variscan zircon grains show corroded cores of also Variscan age, even with more corroded contacts than those with older inherited cores (Fig. 3A, \#4, 10, 14). Inherited cores gave main age clusters at ca. 502-542, 650-690, and 1040-1680 Ma (-rejana et al., 2010). Proterozoic ages are always less than $27 \%$ discordant (-rejana et al., 2011).

\subsection{Granulite xenolith, U152}

Zircons in this granulite are similar in size and shape to those of the previous xenolith (Fig. 3B, \#7, 11, 12, 13, 19, 21). Variscan rounded granulitic zircon crystals give a shorter age range than in the other xenolith: 282-301 Ma (-rejana et al., 2011), with a mean of $287 \pm 2.2 \mathrm{Ma}$. Around $75 \%$ of zircon grains show inherited cores (Fig. 3B, \#2,4,16,17, 18) defining some age clustering at Archean (3371-3453 Ma), Proterozoic (618-662 Ma) and Lower Palaeozoic (440-573 Ma) (Orejana et al., 2011). Most of the bright cores are partially corroded but not showing convoluted or highly lobate shapes (e.g., Fig. 3B, \#16).

\section{Lu-Hf isotopic data}

The Lu-Hf isotopic data obtained for the dated zircons are summarized in Table 1. The zircon Lu-Hf isotopic data are plotted as a function of their crystallization age (Figs. 4 and 5).

The depleted mantle model age ( $T_{\mathrm{DM}}$ ) of a mineral or rock in the continental crust reflects the time elapsed from when the system was last in isotopic equilibrium with a depleted mantle reservoir, and therefore, an estimate of the crustal residence age for the protolith (e.g., Andersen et al., 2002). However, because of the low $\mathrm{Lu} / \mathrm{Hf}$ ratio of zircon, a model age calculated from the measured ${ }^{176} \mathrm{Lu} /{ }^{177} \mathrm{Hf}$ ratio of a zircon gives only a minimum limit for the crustal residence age. A more realistic model age for crustal rocks is to calculate a growth curve for a system with a Lu/Hf ratio corresponding to the average continental crust (0.015), through the zircon initial ${ }^{176} \mathrm{Hf} /{ }^{177} \mathrm{Hf}$ ratio (e.g., Griffin et al., 2002). This twostage model age $\left(T_{\mathrm{DM} 2}\right)$ would provide a better estimate for model ages of the source of granulite-facies rocks presented in this study (Table 1). Nevertheless, model ages potentially represent the accurate timing of the crust generation only if the parental magma lacked a mixed component (Arndt and Goldstein, 1987), otherwise it provides the hybrid age of multicomponents, and consequently a minimum age for the reworked crust (e.g., lizuka et al., 2010).

\subsection{Sotosalbos restite-rich granite, 100560}

The two Variscan narrow rims yield ${ }^{176} \mathrm{Hf} /{ }^{177} \mathrm{Hf}(\mathrm{t})$ of $0.282450-0.282426$ which correspond to $\varepsilon \mathrm{Hf}_{(\mathrm{t})}$ of -4.0 to -4.8 (Figs. 4 and 5). Core analyses of the magmatic protolith (in the age range of $451-467 \mathrm{Ma}$ ) enlarge the ${ }^{176} \mathrm{Hf} /{ }^{177} \mathrm{Hf}(\mathrm{t})$ range, and consequently their corresponding $\varepsilon \mathrm{Hf}_{(\mathrm{t})}$ from +2.4 to -12.5 (Fig. 5). Neoproterozoic core analyses are variable both in age and initial ${ }^{176} \mathrm{Hf} /{ }^{177} \mathrm{Hf}$ ratios (Table 1 ). Two zircon cores yield high positive $\varepsilon \mathrm{Hf}_{(\mathrm{t})}$ values, one is a bright core of $618 \mathrm{Ma}(+9.1)$, whereas +8.5 is shown by the oldest analysed core of $1256 \mathrm{Ma}$. This latter data plots close to the DM evolution line suggesting juvenile addition at that time (Fig. 5). The similarity between the age of this core and its $\mathrm{Hf}$ model age ( $1.4 \mathrm{Ga}$, Table 1 ) agrees well with a crustal production event at that time, which will be further discussed. The $T_{\mathrm{DM} 2}$ range obtained for the Sotosalbos zircons are relatively concentrated from 0.99 to $2.24 \mathrm{Ga}$ (Table 1, Fig. 6), which encompasses the value calculated with the whole-rock Nd depleted model age $(1.7 \mathrm{Ga})$ (Martín Romera et al., 1999).

\subsection{Cervatos leucogranite, CV1}

Variscan zircons yield a range of $0.282479-0.282261$ of initial ${ }^{176} \mathrm{Hf} /{ }^{177} \mathrm{Hf}$ ratios which corresponds to $\varepsilon \mathrm{Hf}_{(\mathrm{t})}$ of -3.4 to -10.9 , wider than that of the Sotosalbos anatectic granite (Figs. 4 and 5). Two Neoproterozoic cores show higher ${ }^{176} \mathrm{Hf} /{ }^{177} \mathrm{Hf}(\mathrm{t})$ values, giving positive $\varepsilon \mathrm{Hf}_{(\mathrm{t})}$ at $561-587 \mathrm{Ma}$ from +0.8 to +5.0 (Table 1 ). Another two Neoproterozoic zircons (one is a core) at 622 and $671 \mathrm{Ma}$ have $\varepsilon \mathrm{Hf}_{(\mathrm{t})}$ of -3.3 and -9.1. Moreover, inherited Palaeoproterozoic-Archean cores also show a varied range of $\mathrm{Hf}$ isotope values, giving $\varepsilon \mathrm{Hf}_{(\mathrm{t})}$ from +4.4 to $-\mathbf{9 . 8}$ (Fig. 5). Most of the Cervatos data yield two-stage Hf model ages of $1.21-2.15 \mathrm{Ga}$, excepting Palaeoproterozoic and Archean zircon cores which gave much older $T_{\mathrm{DM} 2}$ values of $2.5-3.3 \mathrm{Ga}$ (Table 1 ). Published wholerock $\mathrm{Nd}$ depleted model age for this melt-rich migmatite $(1.4 \mathrm{Ga}$, Barbero et al., 1995) is within the calculated $T_{\mathrm{DM} 2}$ range (Fig. 6).

\subsection{Granulite xenolith, $U 145$}

Most of the Variscan zircons have a relatively narrow initial ${ }^{176} \mathrm{Hf} /{ }^{177} \mathrm{Hf}$ range of $0.282625-0.282701$ and a corresponding positive $\varepsilon \mathrm{Hf}_{(\mathrm{t})}$ of +1.3 to +4.1 (Table 1 ). Nevertheless, two spots ( 4.2 and 


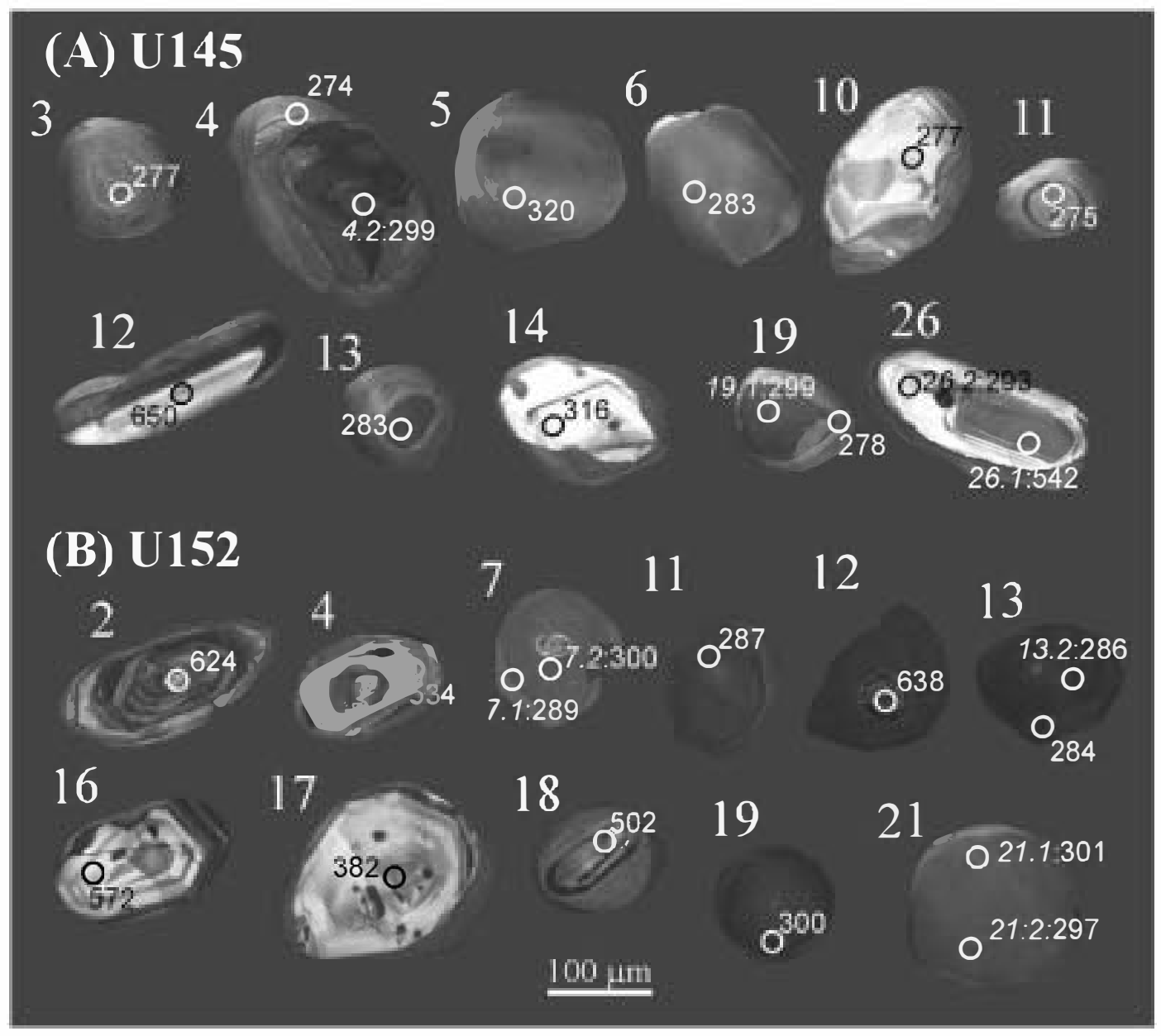

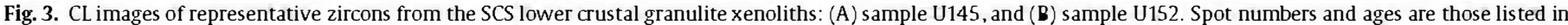
Table 1 .

10.1 ) yield negative $\varepsilon \mathrm{Hf}_{(\mathrm{t})}$ of -1.4 and -9.0 , respectively (Table 1 ), resulting in a marked wider isotopic range when compared with Variscanzircons from the studied CIZ migmatite terranes. The analysed Cambrian cores all give positive $\varepsilon \mathrm{Hf}_{(\mathrm{t})}$ values, from +7.0 to +9.3 , similar to two of the three Neoproterozoic cores (from +0.9 to $+11.0)$, the exception being grain $15.1\left(\varepsilon \mathrm{Hf}_{(\mathrm{t})}=-0.3\right)$, and the oldest zircon core 9.1 which has $\varepsilon \mathrm{Hf}_{(\mathrm{t})}=-6.6$ (Table 1 ). The only analysed core-to-rim grain in this granulite sample (\#26) gave $\varepsilon \mathrm{Hf}_{(293)}$ of $4.0 \pm 1.0(2 \sigma)$ for the core whilst the rim gave $1.3 \pm 1.1(2 \sigma)$ at the same age (Table 1 ), the difference being greater than the analytical uncertainty suggesting preservation of isotopic heterogeneity. When excluding the analysis of Palaeoproterozoic age (\#9.1), the remaining 16 analyses yield a range of $T_{\mathrm{DM} 2}$ from 0.92 to $1.89 \mathrm{Ga}$, which is a similar range to that of the meta-igneous-derived Sotosalbos restite-rich granite. The $\mathrm{Nd}$ model age for this granulite rock (1.4 Ga, Villaseca et al., 1999) is within the range of Hf model ages.

\subsection{Granulite xenolith, $U 152$}

The initial ${ }^{176} \mathrm{Hf} /{ }^{177} \mathrm{Hf}$ ratios for the Variscan zircons are variable (0.282551-0.282026) but mostly showing lower values in comparison to the previous granulite xenolith. They have exclusively negative $\varepsilon \mathrm{Hf}_{(\mathrm{t})}$ values, in the range of -1.6 to -20.1 (Table 1 ). Cambrian - Ediacaran zircon cores (502-573 Ma) have higher ${ }^{176} \mathrm{Hf} /{ }^{177} \mathrm{Hf}(\mathrm{t})$ ratios corresponding to $\varepsilon \mathrm{Hf}_{(\mathrm{t})}$ from -5.7 to +7.4 (Table 1), a much wider range than that obtained for the Variscan zircons. Other Late Neoproterozoic cores (617-649 Ma) yield only negative $\varepsilon \mathrm{Hf}_{(\mathrm{t})}$, in the range of -5.3 to -20.6 (Table 1 ), indistin- guishable within analytical uncertainty from the Variscan zircons. Zircon cores of Archean age yield variable ${ }^{176} \mathrm{Hf} /{ }^{177} \mathrm{Hf}(\mathrm{t})$ values from $0.280469\left(\varepsilon \mathrm{Hf}_{(\mathrm{t})}=-3.4\right)$ to $0.280985\left(\varepsilon \mathrm{Hf}_{(\mathrm{t})}=+13.1\right)$, the latter plotting above the DM evolution line of Fig. 4. Two-stage Hf model ages are mostly from 1.06 to $2.87 \mathrm{Ga}$ (Table 1 ), with a mean of $1.7 \pm 0.2 \mathrm{Ga}(2 \sigma)$, close to the $\mathrm{Nd}$ model age for this rock $(1.5 \mathrm{Ga}$, Villaseca et al., 1999).

\section{Discussion}

\subsection{Presence of Archean components in the SCS lower crust}

Archean continental rocks older than $2.5 \mathrm{Ga}$ are potential sources of unradiogenic $\mathrm{Hf}$ with ${ }^{176} \mathrm{Hf} /{ }^{177} \mathrm{Hf}<0.280$. Archean rocks are unknown in outcropping terranes in the CIZ. However, a scarce population of inherited zircons with ages older than $2.5 \mathrm{Ga}$ has been identified in granulite-facies migmatite terranes (melt-rich migmatites from the ACT, Castiñeiras et al., 2008a,b) and in Variscan S-type granites (Solá et al., 2009; Villaseca et al., unpublished data). The presence of inherited zircons with crustal residence ages older than 2.5Ga (Fig. 6), suggests that Archean protoliths might have been recycled in the lower crust of central Spain. Inherited zircons in granulite U152 showing low values of Hf isotopic ratios also imply the reworking of old crustal material. Archean crustal protoliths have evolved with time towards increasing ${ }^{176} \mathrm{Hf} /{ }^{177} \mathrm{Hf}$ helped by gradual dilution of the Archean component due to invasion by successive Proterozoic juvenile melts. Assuming a ${ }^{176} \mathrm{Lu} /{ }^{177} \mathrm{Hf}$ value of 0.015 as an average crustal reservoir (Griffin 

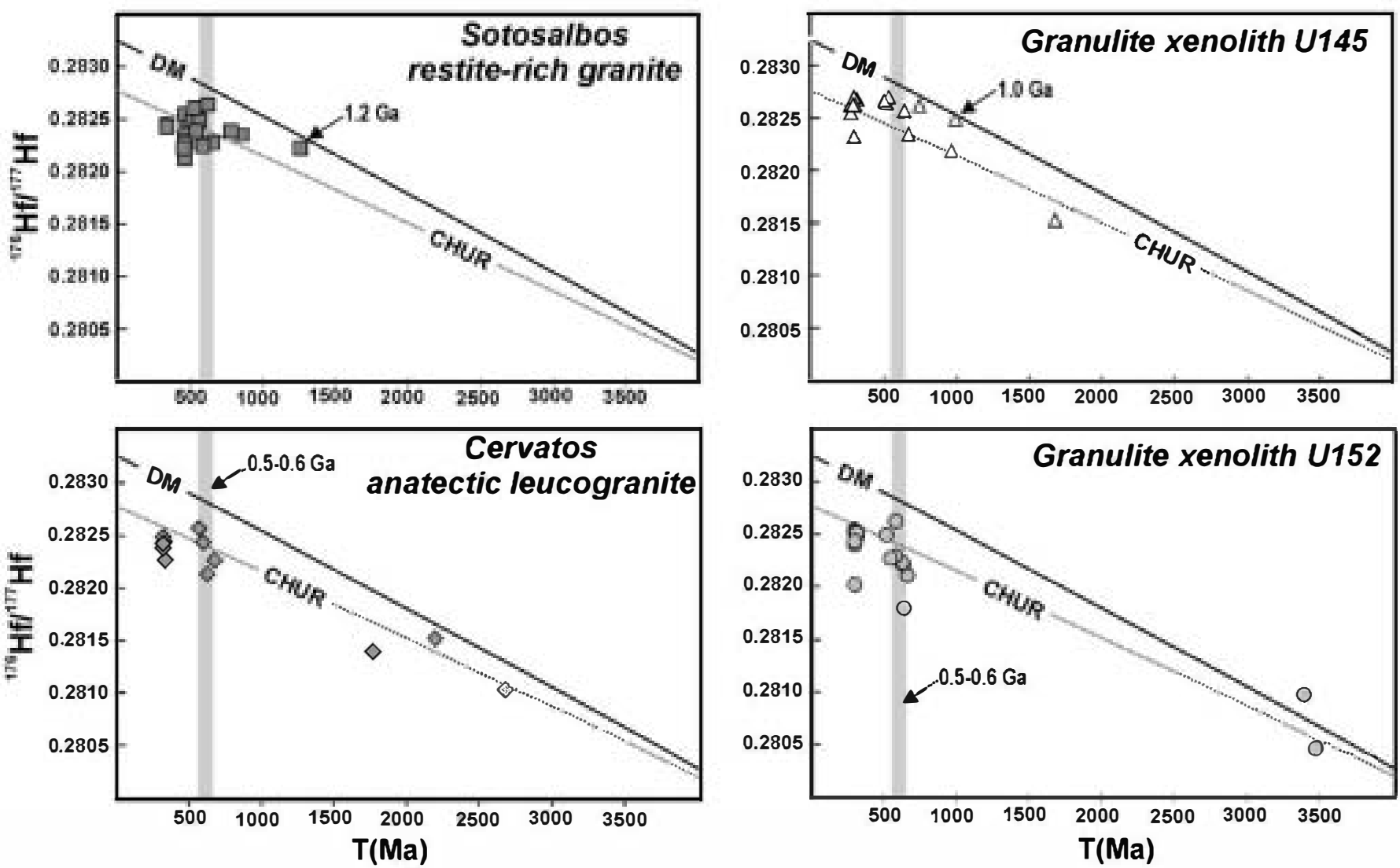

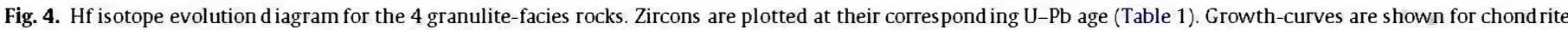
uniform reservoir (CHUR, Blichert-Toft and Albarède, 1997) and depleted mantle (DM, Griffin et al., 2000).

et al., 2002), the zircons with initial ${ }^{176} \mathrm{Hf} /{ }^{177} \mathrm{Hf}<0.28202$ could have been derived from such an Archean component (this includes the Variscan zircon \#5.2 from sample U152, Table 1).

The existence of Archean components in the SCS lower crust has not previously been identified from whole-rock $\mathrm{Nd}$ isotopic data. Much of the Nd model ages of either granulite xenoliths or outcropping metamorphic terranes (both metasedimentary and meta-igneous rocks) yielded values mostly below 2.0Ga (e.g., Villaseca et al., 1998). Nd isotope distribution in granitic rocks from central Spain does not suggest important additions of juvenile continental crust before 2.5 Ga (Villaseca et al., 1998, 2009; Bea et al., 1999). Nevertheless, the calculated two-stage Hf model ages of a $14 \%$ of the zircon population in granulite xenoliths give values over $2.5 \mathrm{Ga}$ (Fig. 6). This data suggests significant Archean components in the residual granulitic lower crust of central Spain, and show that $\mathrm{Hf}$ isotopes combined with $\mathrm{U}-\mathrm{Pb}$ zircon ages is a powerful tool to track juvenile continental crust with time.

Archean components are also present in the studied outcropping granulite-facies migmatites, as proven by U-Pb geochronology and Hf crustal model ages, but they represent a low percentage of their zircon population ( $<6 \%$, leucogranite CV1, Table 1 ). This reinforces the possibility that the lower crust might be significantly older than the exposed crust or, at least that it preserves more ancient crustal material (Belousova et al., 2010).

\subsection{Age of crust-mantle interactions}

The initial Hf isotopic composition of the SCS granulite xenoliths plot between the field of crustal protoliths of different age (Proterozoic to Archean) and the depleted mantle evolution line (Fig. 4). Considering the entire dataset presented in this study, one main event of probable juvenile addition could be defined in cen- tral Spain at 540-620 Ma, with a possible second, weakly defined event around 1.0-1.2 Ga (Fig. 4). Most of the other values that plot above CHUR growth curve could be interpreted as crustal evolution of these two mantle-derived components. Moreover, Hf model age peaks could reflect hybrid ages of multi-juvenile crust formation events (e.g., Arndt and Goldstein, 1987), and for this reason $T_{\mathrm{DM} 2}$ ages will be discussed below for other purposes.

The older event at around 1.0-1.2 Ga is the least defined. One analysis from granulite U145 (\#17.1) plots close to the DM curve making difficult to argue about mixing component processes. This juvenile component also appears in the SCS melt-rich migmatite of Sotosalbos (\#13.1, Fig. 4A), with a similar Hf isotopic signature, although giving a slightly older juvenile addition age than that of the granulite U145. The presence of a significant Mesoproterozoic magmatic event in the SCS granulites would be in contradiction with the dominant idea of a "Mesoproterozoic age gap" (Grenvillian s.l.) typical of the Gondwanan European Variscan terranes (e.g., Kober et al., 2004). Considering that the Grenvillian gap is not merely a sampling problem, it is likely that the scanty evidence of Mesoproterozoic events in U-Pb data is actually a statistically meaningless age cluster (Sánchez-Martínez et al., 2006; Castiñeiras et al., 2008a; Díez Fernández et al., 2010). New insights are gained from our study on $\mathrm{Hf}$ isotope systematics in zircons from highgrade terranes and granulite xenoliths, suggesting that pieces of Mesoproterozoic crust were certainly incorporated into the Gondwana terranes. Alternatively, the scarcity of zircons showing this Mesoproterozoic age range could be due to younger tectonic events producing larger volumes of juvenile crust that may have sufficiently reworked the 1.0-1.2 Ga crust in a way that only a few zircons survived this event. In any case, the suggested possibly minor juvenile addition at $1.0-1.2 \mathrm{Ga}$ is markedly younger than the more widespread crustal-forming events at 1.3-1.6 Ga recorded in 

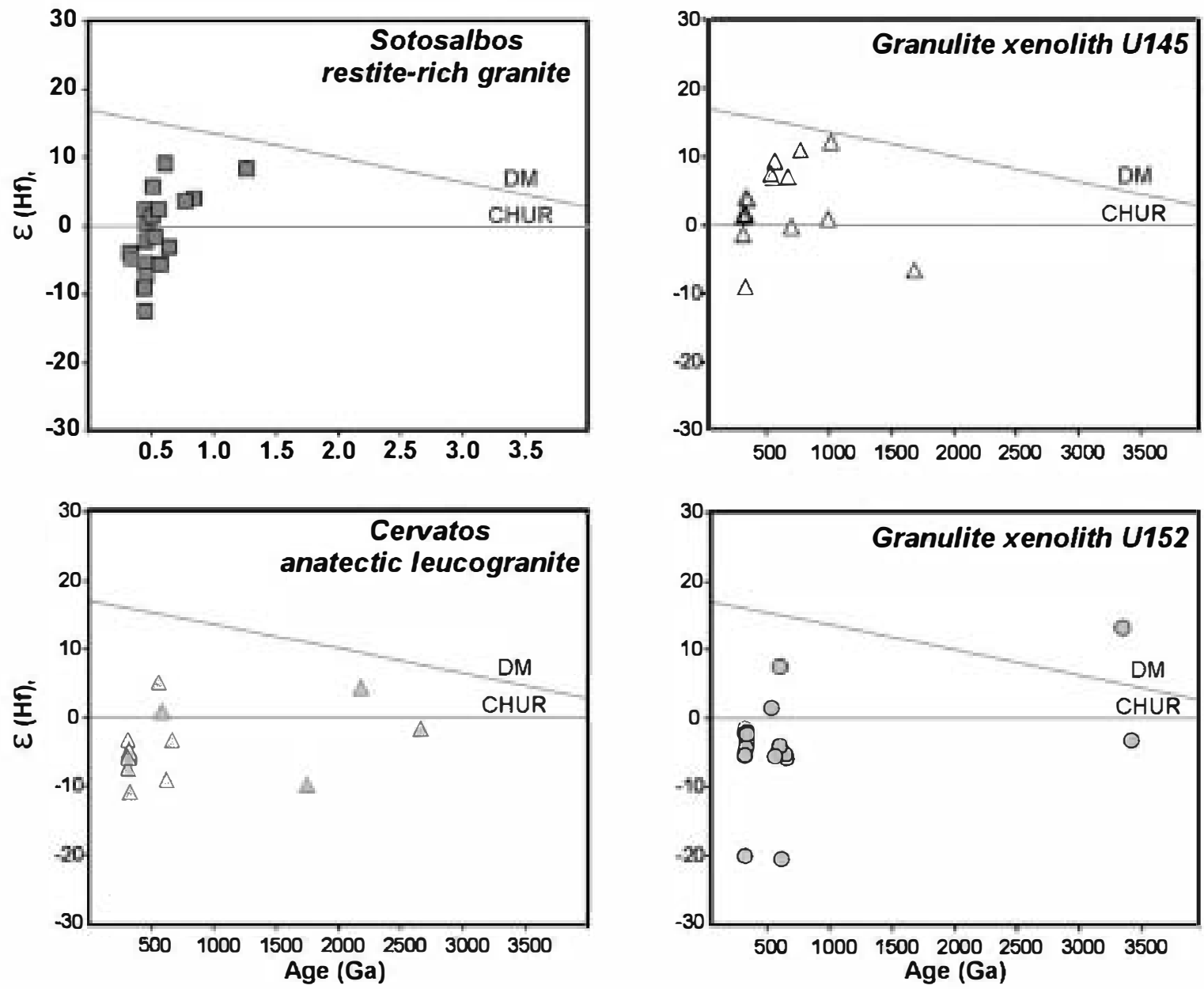

Fig. 5. Initial $\varepsilon$ Hf values of ind ivid ual zircon grains from each of the stud ied granulite-facies rocks. The ages used to calculate the initial values are those from Table 1.

Laurentia, Baltica, Amazonia and Australia(Van Schmus et al., 1996; Condie et al., 2005), and is an important task to address with new Hf isotopic data from previously dated zircons in the 1.0-1.2 Ga time window.

The other, much more significant mantle input could have occurred at 540-620 Ma (Fig. 4). This Neoproterozoic mantle addition is recorded in all the studied granulite-facies rocks, but also in some of the strongly peraluminous granites of the Montes de Toledo Batholith (Villaseca et al., unpublished data). Moreover, 0.5-0.6 Ga metasedimentary and metaigneous series are widespread in the $\mathrm{CIZ}$, defining an important event of crustal growth in central Spain (e.g., López-Guijarro et al., 2008, and references therein). The Neoproterozoic- EarlyCambrian metasedimentary sequences of the southern CIZ (the Schist Greywacke Complex, SGC) have $\mathrm{Sr}$ and $\mathrm{Nd}$ isotopic signatures that have been interpreted as evidence of mixing of juvenile mantle material and pelagic sediments in a poorly defined back-arc zone offshore of the Rodinia supercontinent (Rodríguez-Alonso et al., 2004; López-Guijarro et al., 2008). Moreover, U-Pb zircon ages of metasediments from this SGC have documented two predominant populations of detrital zircons: one c. 1.0-1.2 Ga (Grenvillian) and another c. 0.55-0.65 Ga (Cadomian) (Gutiérrez-Alonso et al., 2003); both these events have been detected in this study for central Spain.

The presence in the Cervatos anatexite and in the granulite xenolith U152 of two old zircon cores ( 2180 and $3371 \mathrm{Ma}$ ) showing marked positive $\varepsilon \mathrm{Hf}_{(\mathrm{t})}$ values $(+4.4$ and +13.1 , respectively), suggests the possibility of other events of juvenile addition during Palaeoproterozoic and Archean times. Hf isotope data are useful for estimating the timing of significant production and/or preservation of juvenile continental crust (e.g., Condie et al., 2009). Fig. 7 summarizes the $T_{\mathrm{DM} 2}$ data from the studied granulitic rocks and their range of whole-rock Nd isotopic data. The resulting juvenile continental growth histogram shows a continuum between 0.95 and $2.3 \mathrm{Ga}$, with the predominance of 1.0-1.8 Ga and peakat 1.6-1.7 Ga (Fig. 7). Nevertheless, $\mathrm{Nd}$ and $\mathrm{Hfm}$ odel ages in the range of 1.4-1.7 Ga might represent mixing of Late Proterozoic juvenile components with variable proportions of older crust of Palaeoproterozoic and possibly Archean age. The presence of very old crustal components in Neoproterozoic - Early Cambrian successions deserves a thorough debate in the future, when forthcoming data from $\mathrm{CIZ}$ metamorphic series are available.

\subsection{Nature of the protoliths of granulite xenoliths}

Hf isotope signatures infer that the protolith of granulite U145 may have been derived from a combination of depleted mantlederived material and old continental rocks. More than $80 \%$ of zircons have positive $\varepsilon \mathrm{Hf}_{(\mathrm{t})}$ values suggesting a strong involvement of juvenile sources in this granulite. The oldest dated zircon in this granulite ( $1681 \mathrm{Ma}$ ) has a highly negative $\varepsilon \mathrm{Hf}_{(\mathrm{t})}$ value $(-6.6$, and a $T_{\mathrm{DM} 2}=2.82 \mathrm{Ga}$, Table 1 ) pointing to the presence of crustal sources with an Archean component. In general,granulite U145 shows similar Hf components as the outcropping SCS metaigneous-derived Sotosalbos melt-rich migmatite, although with a slight tendency towards more radiogenic Hf values (Fig. 4). This is in agreement with the proposed metaigneous origin for most of the SCS lower crustal felsic granulites based on their whole-rock geochemistry 

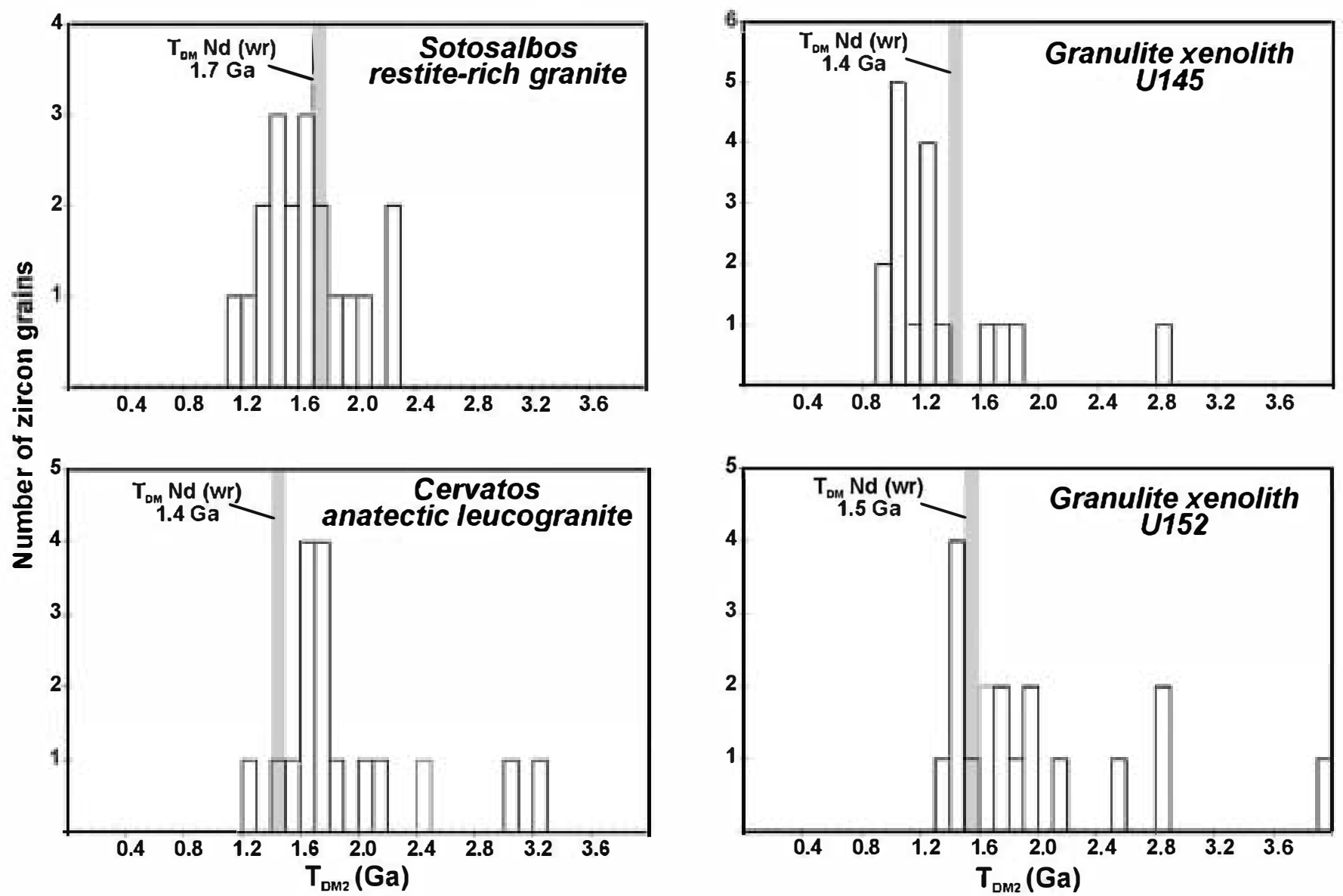

Fig. 6. Histograms of two-stage $\mathrm{Hf}$ model ages $\left(\mathrm{T}_{\mathrm{M} 2}\right)$ of zircons from the four samples. Hf model ages were calculated using an average continental crust Lu/Hf $=0.015$ ( $G$ riffin et al., 2002).

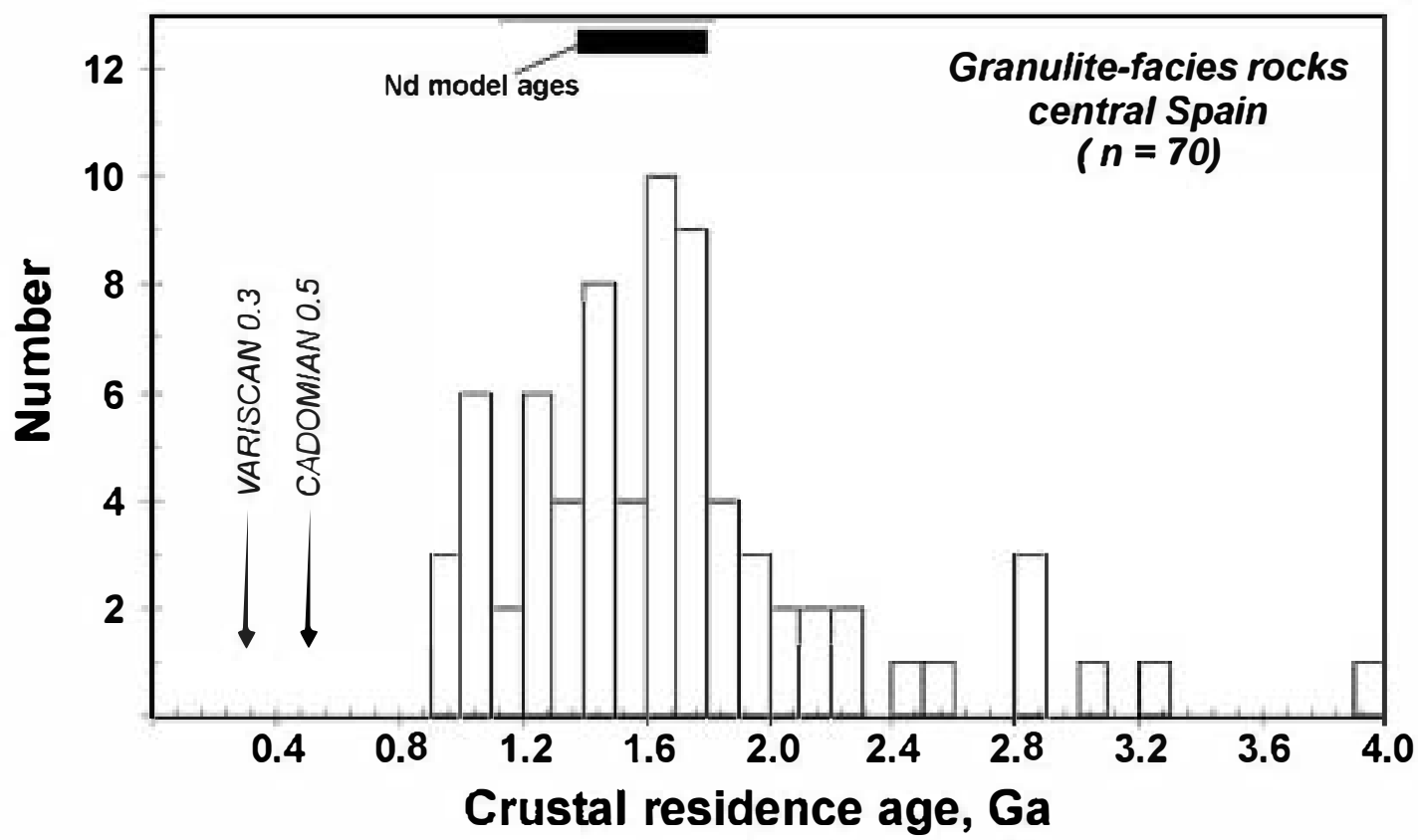

Fig. 7. Histogram of $\mathrm{Hf}$ model ages ( $\mathrm{T}_{\mathrm{M} 2}$ ) of zircons from the four granulite-facies rocks. The range of whole-rock Nd model ages (data taken from: Barbero et al., 1995 ; Martín Romera et al., 1999; Villaseca et al., 1999) is also shown for comparison. 
and $\mathrm{Sr}-\mathbf{N d}$ isotopic data (Villaseca et al., 1999). It is also in accordance with the trace element composition of inherited zircon cores, which show chondrite-normalized REE patterns with steep positive HREE fractionation, and strong positive Ce anomalies and Eu troughs, typical of igneous zircons (-rejana et al., 2011). Moreover, most inherited zircons in this granulite show magmatic oscillatory zoning (Fig. 3A, \#12, 26).

On the contrary, in granulite U152 only 3 zircons out of a total of $19(16 \%)$ display positive $\varepsilon \mathrm{Hf}_{(\mathrm{t})}$ (Fig. 5). This strongly suggests that the sources of these zircons contained a significant amount of old crustal components. Both of the main age groups at $\sim 300$ and 500-660 Ma comprise zircons with chiefly negative epsilon values. The whole-rock $\mathrm{Nd}$ isotopic data yield a negative $\varepsilon \mathrm{Nd}$ value of -5.7 at Variscan times (Villaseca et al., 1999), and an $\mathrm{Nd}$ model age of $1.5 \mathrm{Ga}$, indicating involvement of older crust of at least Palaeoproterozoic age in its source. Moreover, this granulite is the lower crustal xenolith richest in Archean components ( 4 zircons of a total of 19 , i.e., $21 \%$ ) (Fig. 6). The Hf isotope evolution diagram for this granulite resembles that obtained for the Cervatos anatectic leucogranite, which is interpreted as a granitic partial melt derived from metasedimentary sources (Barbero and Villaseca, 1992; Barbero et al., 1995), although with older zircon inheritances (Fig. 4). Nevertheless, the zircon trace element composition, similarly to the other granulite xenolith, is compatible with an igneous protolith (-rejana et al., 2011). This suggests that a complex combination of crustal sources might be involved in the origin of the SCS lower crustal felsic granulites.

\subsection{Hf isotopes and anatexis}

The similarity in Hf isotopic composition between Variscan zircons and Neoproterozoic inherited cores, combined with the common presence of partially corroded cores, suggest that Hf could have been liberated into the anatectic melt by zircon dissolution during migmatization of the protolith (Flowerdew et al., 2006). The spread in ${ }^{176} \mathrm{Hf} /{ }^{177} \mathrm{Hf}$ is less for the rims than the cores in both migmatites (Fig. 4), but most of both ranges overlap when including analytical uncertainties, suggestive of melting and homogenization within a closed system.

However, the above hypothesis is in contradiction with the Hf isotope core-to-rim variation observed in single crystals, rather than considering the whole isotopic range from each sample. Three zoned grains have been analysed in the Sotosalbos migmatite. Two grains have Variscan rims whilst the other is an inherited zoned metaigneous zircon (\#11, 13 and 8, respectively, Table 1). Zircons with Variscan rims show lesser isotopic differences than the other zoned grain (Table 1). For instance, grain 11 has overlapping ${ }^{176} \mathrm{Hf} /{ }^{177} \mathrm{Hf}_{(\mathrm{t})}$ values within errors, whereas in grain 13 the core gave ${ }^{176} \mathrm{Hf} / /^{177} \mathrm{Hf}_{(\mathrm{t})}$ value of $0.282257 \pm 56(2 \sigma)$ whilst therim gave $\mathrm{a}^{176} \mathrm{Hf} /{ }^{177} \mathrm{Hf}(\mathrm{t})$ value of $0.282426 \pm 58(2 \sigma)$. This corresponds to a difference of 6 epsilon units between the core and the rim analyses, when calculated at $339 \mathrm{Ma}$. When compared to grain 8 (without Variscan rim), a difference of more than 13 epsilon units between core and rim analyses (at $451 \mathrm{Ma}$ ) appears. Thus, isotopic heterogeneity is preserved not only during the Ordovician magmatism, but also during Variscan migmatization.

A similar consistent variation between core and rim pairs of about 5-6 epsilon units (higher than analytical errors) in two zoned grains from the Cervatos leucogranite (\#1 and 3, Table 1), suggests that isotopic heterogeneities are preserved during Variscan anatexis. The Hf budget of the partial melts generated in both Variscan migmatite terranes is not controlled by zircon dissolution in a closed system, and breakdown ofless hafnium-rich minerals or partial melting processes involving different isotopic protoliths have to be in consideration. This is in agreement with the general partial melting scenario described for these anatectic areas, where dise-

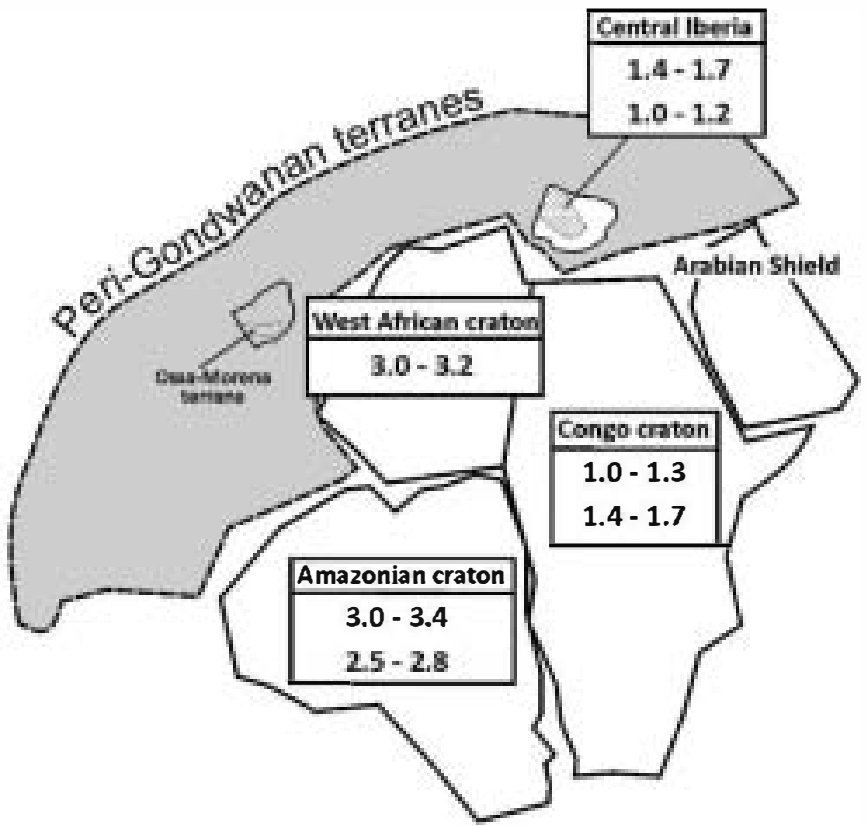

Fig. 8. Geological sketch showing Gondwana and peri-Gondwanan terranes at c. $570 \mathrm{Ma}$ (Linnemann et al., 2007; Díez Fernánd ez et aI., 2010). The hypothetical location of the NW Iberia terrane (mainly the $\mathrm{ClZ}$ ) is placed close to northern Africa, and not paleogeographically related to the Amazonian-West African cratons. On the contrary, SW Iberia is located close to the West African craton(Pereira et al., 2008). Age groups based on Hf model ages ( $T_{\mathrm{M}}$ peaks in relative probability histograms) in the different cratons (Amazonia, West Africa, central Africa) are taken from Key et al. (2008) and lizuka et al. (2010).

quilibrium melting processes and a lack of isotopic homogenization have been described ( Barbero et al., 1995).

\subsection{Tectonic implications of Mesoproterozoic juvenile inheritances in granulites from central Spain}

The cryptic presence of a minor Mesoproterozoic mantle input in the studied granulite-facies rocks from central Spain has to be added to the description of Grenvillian $\mathrm{U}-\mathrm{Pb}$ inheritances detected in metasedimentary series of the southern CIZ (Gutiêrrez-Alonso et al., 2003) and the northern Iberian Massif (Fernández-Suárez et al., 2002, 2000; Castiñeiras et al., 2008b; Díez Fernández et al., 2010). On the contrary, metamorphic series from south-western Spain (e.g., Ossa-Morena Zone, Fig. 1) lack Grenvillian-age zircons and record a population in the range $2.0-2.2 \mathrm{Ga}$ in addition to the widespread Cadomian ages (0.55-0.65Ga) (e.g., López-Guijarro et al., 2008). This has been interpreted considering a tectonic realm where the northern Iberian Massif lay adjacent to the Amazonia continent, whereas the Ossa-Morena Zone may have been close to West Africa by the Neoproterozoic, and that their juxtaposition occurred at around $540 \mathrm{Ma}$ (e.g., López-Guijarro et al., 2008; Pereira et al., 2008). The amalgamation tectonic model is controversial, varying from an accretion achieved by strike-slip faults, due to the absence of clear ophiolitic sequences (Fernández-Suárez et al., 2002), towards models involving an oblique arc-continent collision with Neoproterozoic volcanism in both micro-continental blocks (e.g., Rodríguez-Alonso et al., 2004). Recently, a new model envisaging only African sources for the Mesoproterozoic inheritances in the CIZ metasediments has been proposed (Díez Fernández et al., 2010). In this work, age populations in the interval 800-1250Ma are interpreted as evidence of the location of NW Iberia between the West African craton and the Saharan and Arabian-Nubian shields (Fig. 8). Other authors also place central Iberia in a similar position during the rdovician, based on $\mathrm{U}-\mathrm{Pb}$ ages and whole-rock $\mathrm{Nd}$ 
model ages of lower Palaeozoic metaigneous rocks of the CIZ (Bea et al., 2010). The Hf data presented here record a minor mantle input at 1.0-1.2 Ga in central Iberia, which is markedly younger than the more widespread crustal-forming event at $1.3-1.6 \mathrm{Ga}$ recorded in other continents (e.g., Amazonia, Australia, Ukraine; Van Schmus et al., 1996; Condie et al., 2005). Crustal generation events in central Africa at 1.0-1.3 Ma are recorded in Hf isotopic data in detrital zircons from the Congo River ( Iizuka et al., 2010). The distribution of Hf model ages of the granulite zircons from central Spain matches better the values found in detrital zircons from central Africa (Congo craton) than those from the Amazonian and West African cratons (Fig. 8). This suggests that NW Iberia during early Neoproterozoic and late Mesoproterozoic times was far from the Amazonian craton, and that a position to the north-east of the West African craton might be a more reasonable option(Fig. 8). Palaeogeographic reconstructions for Lower Palaeozoic times based on benthic faunas also suggest that NW Iberia was probably more adjacent to the Algerian Sahara or Libya than to the Moroccan part of the North Gondwanan shelf (Gutierrez-Marco et al., 2002).

\section{Conclusions}

The most significant findings from the present study are:

(i) The Variscan and Cadomian (0.5-0.6Ga) melting events show contribution from both juvenile melt and older sources, but the Late Neoproterozoic event shows a stronger juvenile component than the Variscan one, which is dominantly a crustal reworking event.

(ii) There is cryptic evidence of a Mesoproterozoic 1.0-1.2 Ga event, possibly with a high component of juvenile melt, but it is unlikely that this event is a major crustal component in this region. Additionally, younger orogenic events might have reworked the 1.0-1.2 Ga crust, therefore only a few zircons survived this event.

(iii) Hf isotopic composition of the granulite-facies zircons from central Iberia shows that variable proportions of juvenile versus older component are involved, with the older component most likely dominated by crust of at least Palaeoproterozoic age, and possibly of Archean age.

(iv) Mid-crustal and lower crustal granulites reveal the presence of several Archean inherited zircons and a number of Archean $\mathrm{Hf}$ model ages, indicating that an original Archean age for $\mathrm{CIZ}$ basement is a possibility.

(v) The Hf data recording a minor mantle input at 1.0-1.2 Ga, also found in central Africa detrital zircons, suggest that NW Iberia was far from the Amazonian and West African cratons during Neoproterozoic and Mesoproterozoic times, and that a position closer to central Sahara and Arabian shields might be a more reasonable option, in agreement with recent palaeogeographical models.

\section{Acknowledgements}

We acknowledge Norman Pearson and Rosanna Murphy for their assistance with the LA-ICPMS analyses. Reviews and suggestions byCecilio Quesada and Graham Beggwere greatly appreciated and led to substantial improvement of the original manuscript. This work is included in the objectives of, and supported by, the CGL2008-05952 project of the Ministerio de Ciencia e Innovación of Spain and the GR58/08-910492-UCM project. CV thanks the opportunity to undertake the analytical work in the Geochemical Analysis unit at GEMOC, at Macquarie University. This is contribution 721 from the GEMOC ARC National Key Centre (www.es.mq.edu.au/GEMoc/).

\section{Appendix A. Supplementary data}

Supplementary data associated with this article can be found, in the online version, at doi:10.1016/j.precamres.2011.03.001.

\section{References}

Andersen, T., Griffin, W.L., Pearson, N.J., 2002. Crustal evolution in the SW part of the Baltic Shield: the Hf is otope evidence. Journ al of Petrology 43,1725-1747.

Amdt, N.T., Gold stein, S.L., 1987. Use and abuse of crust-formation ages. Geology 15 $893-895$.

Barbero, L., Villaseca, C., 1992. The L ayos granite, Hercynian Complex of Toled o (Spain): an example of parautochthonous restite-rich granite in a granulitic area. Transactions of the Royal Society of Edinburgh: Earth Sciences 83, 127-138.

Barbero, L. 1995. Granulite-facies metamorphism in the Anatectic Complex of Toled o, Spain: late Hercynian tectonic evolution by crustal extension. Journ al of the Geological Society of Lond on 152, 365-382.

Barbero, L., Villaseca, C., Rogers, G., Brown, P.E., 1995. Geochemical and isotopic diseq uilibrium in crus tal melting: an insight from anatectic granitoid s from Toled o, Spain. Journ al of Geophysical Research 100, 15745-15765.

Barbero, L., Rogers, G., 1999. Implications of U-Pb monazite ages from syn-orogenic granites of the Anatectic Complex of Toled o(Spain) in the evolution of the central part of the Hercynian Iberian Belt. In: D ocuments d u BRGM 290, p. 203.

Barbero, L, Villaseca, C., 2000. Eclogite facies relics in metabasites from the Sierra de Guad arrama (Spanish Central System): P-T estimations and implications for the Hercynian evolution. Mineralogical Magazine 64, 815-836.

Bea,F., Pereira, M.D., Stroth,A., 1994. Mineral/leucosome trace element partitioning in a peraluminous migmatite (a laser ablation-ICP-MSstudy). Chemical Geology 117,291-312.

Bea,F., Montero, P., Molina,J.F., 1999. Mafic precursors, peraluminous granitoid s, and late lamprophyres in the Avilabatholith: a model for the generation of Variscan batholiths in Iberia. Journal of Geology 107, 399-419.

Bea, F., Montero, P., González-Lodeiro, F., Talavera, C., Molina, JF., Scarrow, J.H., Whitehouse, M.J., Zinger, T., 2006. Zircon thermometry and U-Ph ionmicroprobe dating of the gabbros and associated migmatites of the Variscan Toled o Anatectic Complex, Central Iberia. Journal of the Geological Society of Lond on $163,847-855$.

Bea, F. Montero, P., González-L odeiro, F., Talavera, C., 2007. Zircon inheritance reveals exceptionally fast crustal magma generation processes in Central Iberia during the Cambro-Ord ovici an. Journ al of Petrology 48, 2327-2339.

Bea, F., Montero, P., Talavera, C., Abu Anbar, M., Scarrow, J.H., molina, J.F., Moreno, J.A., 2010. The palaeogeographic position of Central Iberia in Gondwana during the Ordovician: evidence from zircon chronology and Nd isotopes. Terra Nova $22,341-346$.

Belousova, E.A., Kostitsyn, Y.A., Griffin, W.I., Beggs, G.C., O’Reilly, S.Y., Pearson, N.J., 2010. The growth of the continental crust: constraints from zircon Hf-isotope data. Lithos, d oi:10.1016/j.lithos.2010.07.024.

Blichert-Toft, J., Albarède, F., 1997. The Lu-Hf geochemistry of chond rites and the evolution of the mantle-crust system. Earth and Planetary Science Letters 148, 243-258.

Bouvier A. Vervoot, J.D. Patchett, P. J. 2008. The Lu-Hfand Sm-Nd isotopic composition of CHUR: constraints from unequilibrated chond rites and implications for the bulk composition of terrestrial planets. Earth and Planetary Science Letters 273,48-57.

Brown, M., 2001. Crustal melting and granite magmatism: key issues. Physics and Chemistry of the Earth $26,201-212$

Castiñeiras, P., Villaseca, C., Barbero, L., Martín Romera, C., 2008a. SHRIMP U-Pb zircon dating of anatexis in high-grade migmatite complexes of Central Spain: implications in the Hercynian evolution of central Iberia. Intern ational Journ al of Earth Sciences $97,35-50$

Castiñeiras, P., Navid ad, M., Liesa, M., Carreras, J., Casas, J.M., 2008b. U-Pb zirconages (SHRIMP) for Cadomian and Early Ordovician magmatism in the Eastern Pyrenees: new insights into the pre-Variscan evolution of the northern Gondwana margin. Tectonophysics 461, 228-239.

Cherniak, D.J., Watson, E.B., 2003. Diffusion in zircon. Reviews in Mineralogy and Geochemistry 53, 113-143.

Clemens, J.D., 1990. The granulite-granite connexion. In: Vielzeuf, D., Vidal, Ph (Eds.), Granulites and Crustal differentiation. Kluwer Academic Publishers, Dord recht, pp. 25-36

Cond ie, K.C., Beyer, E., Belousova, E., Griffin, W.L., O'Reilly, S.Y., 2005. U-Ph isotopic ages and $\mathrm{Hf}$ isotopic composition of single zircons: the search for juvenile Precambrian continental crust. Precambrian Research 139, 42-100.

Cond ie, K.C., Belousova, E., Griffin, W.L., Sircombe, K.N., 2009. Granitoid events in space and time: constraints from igneous and detrital zircon age spectra. Gondwana Research $15,228-242$.

Díez Fernández, R., Martínez Catalán,J.R., Gerdes, A., Abati,J., Arenas, R., FemándezSuárez, J., 2010. U-Ph ages of detrital zircons from the Basal allochthonous units of NW Iberia: provenance and palaeoposition on the northern margin of Gond wana during the Neoproterozoic and Paleozoic. Gond wana Research. d oi:10.1016/j.gr2009.12.006

Escuder Viruete, J., Hern áiz, P.P., Valverd e-Vaq uero, P., Rod ríguez, R., D unning, G., 1998. Variscan syncollisional extension in the Iberian Massif: structural, metamorphic and geochronological evidence from the Somosierra sectorofthe Sierra de Guad arrama (Central Iberian Zone, Spain). Tectonophysics 290,87-109. 
Fernández-Suárez, J., Gutié rrez-Alonso, G., Jenner, G.A., Tubrett, M.N., 2000. New id eas on the Proterozoic-E arly Palaeozoic evolution of NW Iberia: insights from U-Ph detrital zircon ages. Precambrian Research 102, 185-206.

Fernández-Suárez,J., Gutié rrez-Alonso, G., Jeffries, T., 2002. The importance of alongmargin terrane transport in northern Gondwana: insights from detrital zircon parantage in Neoproterozoicrocks from Iberia and Brittany. Earth and Planetary Science Letters 202,75-88.

Fernández-Suárez, J., Arenas, R., Jeffries, T.E., Whitehouse, M.J., Villaseca, C. , 2006. A U-Ph study of zircons from a lowercrus tal granulite xenolith of the Spanish Central system: a record of lberian lithospheric evolution from the Neoproterozoic to the Triassic. Journal of Geology 114, 471-483.

Flowerdew, M. J., Millar, I.L., Vaughan, A.P.M., Horstwood, M.S.A., Fanning, C.M., 2006. The source of granitic gneisses and migmatites in the Antarctic peninsula: a combined U-Ph SHRIMP and laser ablation Hf isotope study of complex zircons. Contributions to Mineralogy and Petrology 151, 751-768.

Griffin, W.L., Pearson, N.J., Belousova, E., Jackson, SE., van Achterbergh, E., O'Reilly, S.Y., Shee, S.R., 2000. The Hf isotope composition of cratonic mantle: IAM-MCICPMS analysis of zircon megacrys ts in kimberlite. Geochimica et Cos mochimica Acta 64, 133-147.

Griffin, W.L., Wang, X., Jackson, S.E., Pearson, N.J., O’Reilly, S.Y., Xu, X., Zhou, X., 2002. Zircon chemistry and magma mixing, SE China: in situ analysis of Hf isotopes, Tonglu and Pingtan igneous complexes. Lithos 61,237-269.

Griffin, W.L., Belousova, E., Shee, S.R., Pearson, N.J., O’Reilly, S.Y., 2004. Archean crustal evolution in the northern Yilgarn Craton: $\mathrm{U}-\mathrm{Pb}$ and $\mathrm{Hf}$-isotope evidence from detrital zircons. Precambrian Research 131,231-282.

Gutié rrez-Alonso, G., Fernández-Suárez, J., Jeffries, T., Jenner, G.A., Tubrett, M.N., Cox, R., Jackson, S.E., 2003. Terrane accretion and dispersal in the northern Gond wana margin. An Early Palaeozoic analogue of a long-lived active margin. Tectonophysics 365, 221-232.

Gutierrez-Marco,J.C., Robard et, M., Rábano,I., Sarmiento, G.N., SanJ osé Lancha, M.A., Herranz, P., Pieren, A.P., 2002. Ord ovician. ln: Gibbons, W., Moreno, T. (E ds.), The Geology of Spain. The Geological Society of Lond on, pp. 31-49.

lizuka, T., Komiya, T., Rino, S., Maruyama, S., Hirata, T., 2010. Detr ital zircon evidence for Hf isotopic evolution of granitoid crust and continental growth. Geochimica et Cosmochimica Acta 74, 2450-2472.

Julivert, M., Fontboté, J.M., Ribeiro, A., Conde, L.N., 1972. Mapa Tectónico de la península lbérica y Baleares E 1:1000000. Instituto Geológico y Minero de España, Madrid.

Key, R.M., Loughlin, S.C., Gillespie, M., Del Rio, M., Horstwood, M.S.A., Crowley, Q.G., D arbyshire, D.P.F., Pitfield, P.E.J., Henney, P.J., 2008. Two Mesoarchean terranes in the Reguibat shield of Mauritania. Geological Soci ety of Lond on, Special Publications 297, 33-52.

Kober, B., Kalt, A., Hanel, M., Pidgeon, R.T., 2004. SHRIMP d ating of zircons from highgrade metased iments of the Schwarzwuald/SW-Germany and implications for the evolution of the Mold anubian basement Contributions to Mineralogy and Petrology 147,330-345

Linnemann, U., Gerdes, A., Drost, K., Buschmann, B., 2007. The continuum between Cadomian orogenesis and the opening of the Rheic ocean: constraints from IA-ICP-MS U-Ph zircon dating and analysis of plate-tectonic setting (SaxoThuringian zone, northeastern Bohemian Massif, Germany). Geological Society of America Special Paper 423, 61-96.

Liu, F., Robinson, P.T., Gerdes, A., Xue, H., Liu, P., Liou, J.G., 2010. Zircon U-Pb ages, REE concentrations and Hfis otrope compositions of granitic leucosome and pegmatite from the north Sulu UHP terrane in China: constraints on the timing and nature of partial melting. Lithos 117,247-268.

López-Guijarro, R., Armend áriz, M., Quesada, C., Fernández-Suárez, J., Murphy, B., Pin, C., Bellido, F., 2008. Ediacaran-Palaeozoic evolution of the Ossa Morena and Central Iberian zones (SW Iberia) as revealed by $\mathrm{Sm}-\mathrm{Nd}$ isotope systematics. Tectonophysics 461, 202-214

Martín Romera, C., Villaseca, C., Barbero, L., 1999. Materiales anatécticos en el área de Sotosalbos (Segovia, Sierra de Guad arrama). In: Caracterización petroló gica, geoquímica e isotó pica (Sr, Nd). Actas II Congreso Ibérico de Geoquímica, Lisboa, pp. 329-332.
Orejana, D., Villaseca,C., Armstrong, R.A., Jeffries, T., 2011. Geochronology and trace element chemistry of zircon and garnet from granulite xenoliths: constraints on the tectonothermal evolution of the lower crust under central Spain. Lithos, d oi:10.1016/j.lithos.2010.10.011.

Pereira, M.D., Rodńguez Alonso, M.D., 2000. Duality of cord ierite granites related to melt-restite segregation in the Peña Negra anatectic complex, central Spain. Canadian Mineralogist 38, 1329-1346.

Pereira, M.F., Chichorro, M., Williams, IS., Silva,J.B., 2008. Zircon U-Ph geochronology of paragneisses and biotite granites from the SW Iberian Massif (Portugal): evidence for a palaeogeographical link between the Ossa-Morena Ediacaran basins and the West African craton. Geological Society of Lond on, Special Publications 297, 385-408.

Pidgeon, R.T., Nemchin, A.A. Hitchen, G.J., 1998. Internal structures of zircon from Archeangranites from the D arling Range batholith: implications for zircon stability and the interpretation of zircon U-Pb ages. Contributions to Mineralogy and Petrology $132,288-299$.

Rod ríguez-Alonso, M.D., Peinad o, M., Ló pez-Plaza, M., Franco, P., Carnicero,A., Gonzalo, J.C., 2004. Neoproterozoic-Cambrian synsed imentary magmatis $m$ in the Central Iberian Zone (Spain): geology, petrology and geod ynamic significance. International Journal of Earth Sciences 93,897-920.

Rosenberg, C.L., Handy, M.R., 2005. Experimental deformation of partially melted granite revisited : implications for the continental crust. Journal of Metamorphic Geology 23, 19-28

Sánchez-Martínez, S., Jeffries, T., Arenas, R. ,Fernánd ez-Suárez, J., Garáa-Sánchez, R. 2006. A pre-Rodinian ophiolite involved in the Variscan suture of Galicia (Cabo Ortegal Complex, NW Spain). Journal of the Geological Society of Lond on 163. 737-740.

Scherer, E.E., Mi inker, C., Mezger, K., 2001. Calibration of the lutetium-hafnium cl ock. Science 293, 683-687.

Solá,A.R., Williams,IS., Neiva, A.M.R., Ribeiro, M.L., 2009. U-Th-Pb SHRIMP ages and oxygen isotope composition of zircon from two contrasting late Variscan granitoid s, Nisa-Alburq uerq ue batholith, SW Iberian Massif: petrologic and regional implications. Lithos 111, 156-167.

Van Schmus, W.R., Bickford, M.E., Turek, A., 1996. Proterozoic geology of the eastcentral midcontinent basement. Geological Society of America Special Paper $308,7-32$.

Villaseca, C., Barbero, L., Rogers, G., 1998. Crustal origin of Hercynian peraluminous granitic batholiths of Central Spain: petrological, geochemical and isotopic ( $\mathrm{Sr}$, Nd) constraints. Lithos 43, 55-79.

Villaseca, C., Downes, H., Pin, C., Barbero, L. 1999. Nature and composition of the lower continental crust in central Spain and the granulite-granite linkage: inferences from granulitic xenoliths. Journal of Petrology 40 , 1465-1496

Villaseca, C., Martín Romera,C., Barbero, L., 2001. Melts and residua geochemistry in a low-to-mid crustal section (Central Spain). Physics and Chemistry of the Earth $26,273-280$

Villaseca, C., Ubanell, A.G., 2005. El macizo metagranítico de La Cebollera (Pico de las Tres Provincias, Somosierra, Sistema Central Español): nuevos datos sobre el metamorfismo Hercínico del sector de Somosierra. Revista de la Socied ad Geoló gica de España 18, 115-131.

Villaseca, C., Orejana,D., 2008. Rutilos ricos en $\mathrm{Zr}$ incluid os en granates de xenolitos granulíticos de la corteza inferior del Sistema Central Español: implicaciones geodinámicas. Geogaceta 44, 31-34.

Villaseca, C., Bellido, F., Pérez-Soba, C., 2009. Multiple crustal sources for posttectonic I-type granites in the Hercynian Iberian Belt. Mineralogy and Petrology $96,197-211$

Woodhead, J.D., Hergt, J.M., 2005. A preliminary appraisal of seven natural zircon reference materials for in situ Hf isotope determinations. Geostandards and Geoanalytical Research 29, 183-195.

Wu, Y.B., Zheng, Y.F., Zhang, S.B., Zhao, Z.F., Wu, F.Y., Liu, X.M., 2007. Zircon U-Pb ages and $\mathrm{Hf}$ isotope compositions of migmatite from the North Dabie terrane in China: constraints on partial melting. Journal of Metamorphic Geology 25 , 991-1009. 